\title{
Cryptogam covers on sepulchral monuments and re-colonization of a marble surface after cleaning
}

\author{
Christine Hallmann • Wanja Wedekind • \\ Dorothea Hause-Reitner • Michael Hoppert
}

Received: 1 October 2012/ Accepted: 29 December 2012/Published online: 23 January 2013

(C) The Author(s) 2013. This article is published with open access at Springerlink.com

\begin{abstract}
Re-colonization of freshly cleaned surfaces by aeroterrestrial microbial communities is up to now poorly understood. Here, we present a comparative study addressing the composition of algal and fungal communities on a marble sculpture, based upon the analysis of $18 \mathrm{~S}$ rRNA gene clone libraries from environmental samples. The samples were taken from a blackish and greenish biofilm cover before surface cleaning and 1 year after cleaning treatment, when traces of re-colonization became visible to the naked eye. The composition of the fungal community indicated clear differences between the old grown biofilm and the treated surface. While the former was dominated by the ascomycetes Rhinocladiella, Glyphium and Capnodiales, the black yeast Sarcinomyces was clearly dominant 1 year after cleaning, but could not be retrieved from the old grown black biofilm. The green algal community was dominated by different phylotypes of
\end{abstract}

\section{Hallmann $(\square)$}

Department of Experimental Phycology and Culture Collection of Algae (SAG), Albrecht-von-Haller-Institute for Plant Sciences, Georg-August-University, Untere Karspüle 2, 37073 Göttingen, Germany

e-mail: challma@gwdg.de

W. Wedekind

Department of Structural Geology, Geoscience Centre,

Georg-August-University, Goldschmidtstraße 3,

37077 Göttingen, Germany

D. Hause-Reitner · M. Hoppert

Courant Research Centre Geobiology, Georg-August-University,

Goldschmidtstraße 3, 37077 Göttingen, Germany

M. Hoppert

Institute for Microbiology and Genetics,

Georg-August-University, Grisebachstraße 8,

37077 Göttingen, Germany the lichen algae Trebouxia, as well as the cosmopolitan green algae Apatococcus and Stichococcus. No essential differences in the green algal community before and after cleaning could be observed.

Keywords Environmental samples · Fungi ·

Green algae $\cdot$ Lichen $\cdot 18 \mathrm{~S}$ rRNA gene

\section{Introduction}

Open-air sculptures and historic buildings exposed to weather and pollution are deteriorated by physical and chemical factors, as well as by microbial contamination (Saiz-Jimenez 1995; Zanardini et al. 2000; Polo et al. 2010).

Microbial communities on stone surfaces are composed of bacteria including cyanobacteria, fungi, algae and lichens (Warscheid and Braams 2000; McNamara and Mitchell 2005). Phototrophs, like cyanobacteria and algae, are primary colonizers (Grant 1982) and also provide nutrients for heterotrophic microorganisms, e.g., fungi (Gaylarde et al. 2012). All these microorganisms may be involved in biodeterioration, e.g., biopitting by penetration of fungi in the material surface but also as staining caused by algae and black pigmented fungi (Sterflinger and Krumbein 1997; McNamara et al. 2006; Polo et al. 2010 and references therein). A multitude of studies documented the deterioration of marble monuments and building facades by weathering, pollution and microbial communities (Gromov 1963; Lamenti et al. 2000; Gorbushina et al. 2002; Moropoulou et al. 2002; Cappitelli et al. 2007; Weber et al. 2007; Sert and Sterflinger 2010; Hallmann et al. 2011a).

Different cleaning methods and conservation procedures were developed, based on chemical compounds (Young 
and Urquhart 1998; Moropoulou et al. 2002; Polo et al. 2010), excimer laser cleaning (Maravelaki-Kalaitzaki et al. 1999), protective synthetic resins (Cappitelli et al. 2007) or application of biomimetic apatite (Yang et al. 2012). Even biological treatments with sulfate reducing bacteria for black crust removal were established (Cappitelli et al. 2006; Konkol et al. 2008).

So far only few studies were devoted to comparative analysis concerning re-colonization by microorganisms after cleaning procedures. Lamenti et al. (2000) observed the re-colonization of marble statues by phototrophic biofilms for 6 years after restoration by culturing method. Polo et al. (2010) analyzed microbial communities by denaturing gradient gel electrophoresis (DGGE) before and immediately after biological and chemical remediation of oolithic limestone sculptures. Lan et al. (2010) stated obvious differences between the eukaryotic community of an old and a newly developed biofilm on sandstone of a Temple building of Angkor Thom in Cambodia, while the bacterial communities of both biofilms were almost similar.

In our study, an "old grown" blackish and greenish biofilm (surface left untreated tens of years) and a newly developed biofilm on the surface of a sepulchral marble sculpture 1 year after cleaning were analyzed and compared by environmental cloning and sequencing. The focus was on green algal and fungal communities, to identify the emerging colonizers in an early period of (re-) colonization.

\section{Materials and methods}

\section{Sampling}

The sampling site was a marble sculpture on the historical Bartholomäus cemetery in Göttingen, Lower Saxony, Germany $\left(51^{\circ} 32^{\prime} 27.49^{\prime \prime} \mathrm{N}, 9^{\circ} 55^{\prime} 54.52^{\prime \prime} \mathrm{E}\right)$. The sculpture was created in 1802 by the sculptor Johann Christian Ruhl (1764-1842) and was placed on the grave of Carl von Hahn. The grave was situated under a tree and near a main street.

The sculpture, made of Tuscan Carrara marble, was covered with a blackish and greenish biofilm dominated by fungi and green algae. At some spots, also crustose and foliose lichens were abundant (cf. Figs. 1a, b and 2a). The grave was restored in 2009/2010, including a surface cleaning of the sculpture. The cleaning was performed as follows: the cryptogam cover was removed with soft brushes and wooden tools; then, the surface was cleaned with a vapor stem cleaner. Since dark stains could be not removed by this procedure, the surface was treated several times with a diluted hydrogen peroxide solution. A resulting foam layer on the surface was removed by rinsing with water. The surface was then impregnated with a thin layer of calcium silicate. A small area situated on the back of the sculpture was left untreated. All samples were collected in April 2011, 1 year after cleaning and restoration. Samples of approx. 100- $\mu$ l dry volume were taken from the cleaned white marble monument ("cleaned surface", sample A) and from the small area covered with the old grown black biofilm ("uncleaned surface", sample B) which had been left untreated during cleaning. The samples were scraped off with a sterile scalpel and collected in sterile $1.5-\mathrm{ml}$ reaction tubes.

\section{DNA extraction}

Genomic DNA was extracted from collected environmental biofilm samples. For the cell disruption by shaking in a Mini-Beadbeater (Biospec Products, Bartlesville, OK, USA) equivalent amounts of acid washed glass beads (120-200 $\mu \mathrm{m}$ and 425-600 $\mu \mathrm{m}$ in diameter; SigmaAldrich, ST. Louis, MO, USA) were added to 2-ml reaction tubes containing the samples. The samples were treated in the beadbeater for $30 \mathrm{~s}$ at 5,000 rpm. DNA was extracted with the Invisorb ${ }^{\circledR}$ Spin Plant Mini Kit (STRATEC Molecular, Berlin, Germany), following the manufacturer's instructions. Extraction results were checked on a $1 \%$ (w/v) agarose gel. Isolated DNA was stored at $-20{ }^{\circ} \mathrm{C}$ until further processing.

\section{Polymerase chain reaction amplification}

For isolated biofilm DNA the polymerase chain reaction (PCR) amplification was performed with two primer combinations for 18S rRNA gene, using eukaryotic standard primers 20F (5' GTAGTCATATGCTTGTCTC $3^{\prime}$ ) and 18L (5' CACCTACGGAAACCTTGTTACGACTT 3'; Hamby et al. 1988). In a second approach, the samples were first amplified with $20 \mathrm{~F} / 18 \mathrm{~L}$ and in a second round (semi-nested PCR) with $20 \mathrm{~F}$ and the green algal-specific primer CH1750R (5' CTTCCTCTAGRTGGGAGG 3'; Hallmann et al. 2013). About $30 \mathrm{ng}$ of the extracted DNA was used as template. The amplification reaction mixture $(25 \mu \mathrm{l})$ contained each dNTP at a concentration of $0.1 \mathrm{mM}$, $5 \mu$ of $10 \times$ reaction buffer, $2 \mathrm{mM} \mathrm{MgCl}_{2}$, each primer at a concentration of $0.2 \mu \mathrm{M}, 2 \mathrm{U}$ of Taq DNA polymerase (Bioline, Luckenwalde, Germany) and $4 \%$ (v/v) dimethyl sulfoxide (DMSO)-solution. PCR was performed in a thermocycler TProfessional Basic (Biometra, Göttingen, Germany) using the following program for the primer set 20F/18L: initial denaturation at $95^{\circ} \mathrm{C}$ for $5 \mathrm{~min}$, followed by 35 cycles of denaturation at $94{ }^{\circ} \mathrm{C}$ for $1 \mathrm{~min}$, annealing at 50 ${ }^{\circ} \mathrm{C}$ for $1 \mathrm{~min}$, extension at $72{ }^{\circ} \mathrm{C}$ for $3 \mathrm{~min}$ and final extension at $72{ }^{\circ} \mathrm{C}$ for $10 \mathrm{~min}$. For the semi-nested PCR with the primer set $20 \mathrm{~F} / \mathrm{CH} 1750 \mathrm{R}$, the first PCR product of $20 \mathrm{~F} /$ $18 \mathrm{~L}$ was diluted 1:25 and used as template; then the 

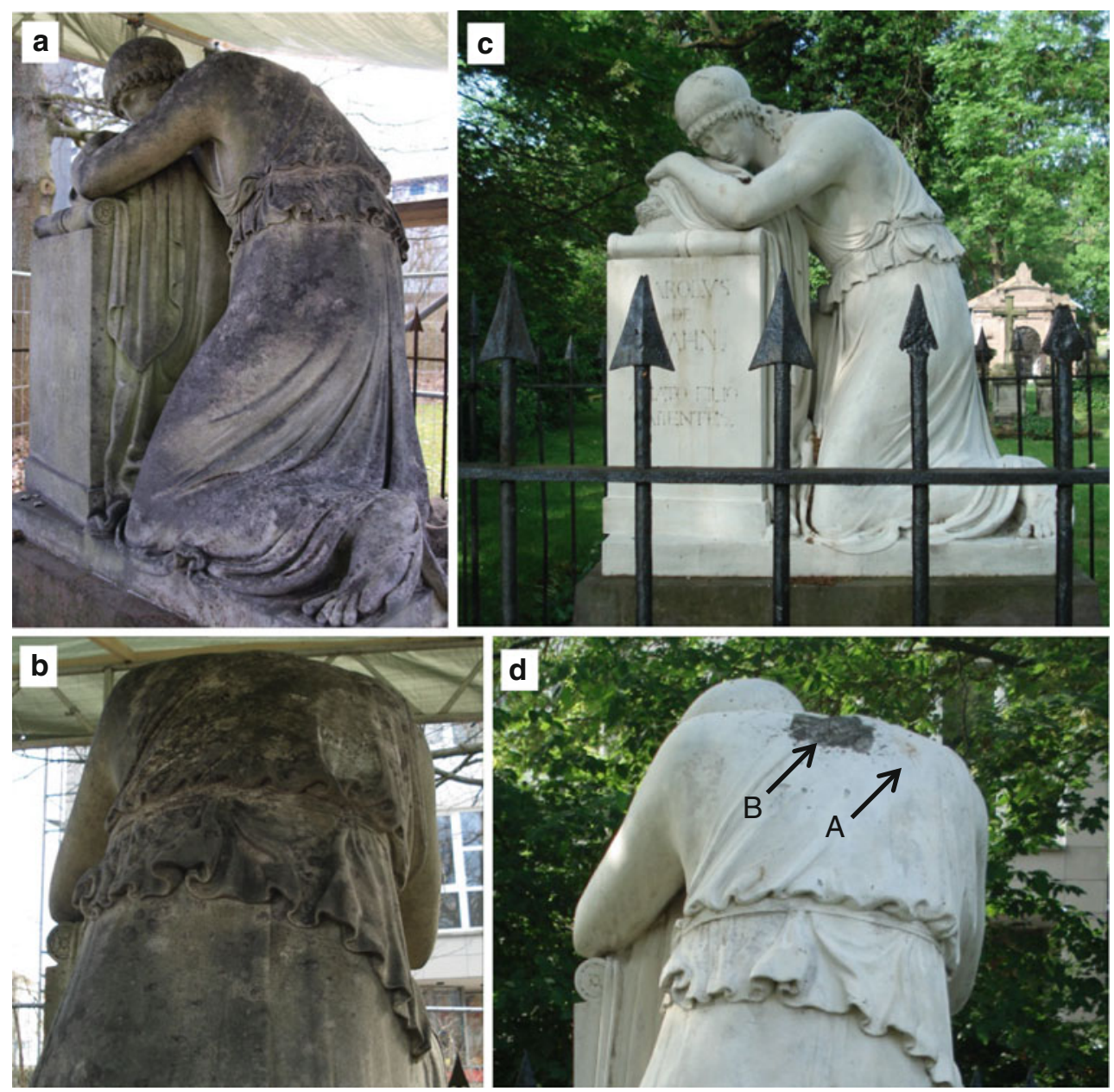

Fig. 1 Sampling site on sepulchral monument. a Monument covered with blackish and greenish biofilm. bBack view of the untreated monument. c Monument 1 year after cleaning treatment. dBack view

following program was used: initial denaturation at $95{ }^{\circ} \mathrm{C}$ for $5 \mathrm{~min}$, followed by 25 cycles of denaturation at $94{ }^{\circ} \mathrm{C}$ for $1 \mathrm{~min}$, annealing at $54^{\circ} \mathrm{C}$ for $1 \mathrm{~min}$, extension at $72^{\circ} \mathrm{C}$ for 3 min, and final extension at $72{ }^{\circ} \mathrm{C}$ for $10 \mathrm{~min}$.

The PCR products were purified using the Invisorb $^{\circledR}$ Spin PCRapid Kit (STRATEC Molecular). Aliquots of $2 \mu \mathrm{l}$ of purified amplicons were analyzed by electrophoresis on a $1 \%(w / v)$ agarose gel.

18S rRNA gene cloning and sequencing

Cloning was carried out with the TOPO TA cloning kit (Invitrogen, Carlsbad, CA, USA) with TOP 10 chemically competent one Shot Escherichia coli cells (Invitrogen), as supplied by the manufacturer. All eukaryotic clones were sequenced with the 18S rRNA gene standard sequencing primer 895R (5' AAATCCAAGAATTTCACCTC $\left.3^{\prime}\right)$ resulting in partial sequences including the hypervariable after cleaning. The arrows mark the sites where samples A and B were taken ( $A$ cleaned surface, $B$ uncleaned surface)

regions V2-V4 (Hodač et al. 2012). Sequencing reactions were performed by Macrogen Inc. (Seoul, South Korea).

Phylogenetic analysis

The sequences were manually corrected using the sequence analysis program SeqAssem (Hepperle 2004). Sequences shorter than $400 \mathrm{bp}$ were excluded from further analysis. These sequences were compared with similar sequences of reference organisms by performing a BLASTN search at NCBI (Altschul et al. 1990; http://www.ncbi.nlm.nih.gov/). Next relative sequences were imported into the ARB program (Ludwig et al. 2004, http://www.arb-home.de). In addition, sequences provided by SAG Culture Collection of Algae (University of Göttingen) were included in the comparisons. To determine the first phylogenetic affiliation the partial sequences were aligned with the homologous eukaryotic $18 \mathrm{~S}$ rRNA gene sequences using the automatic 

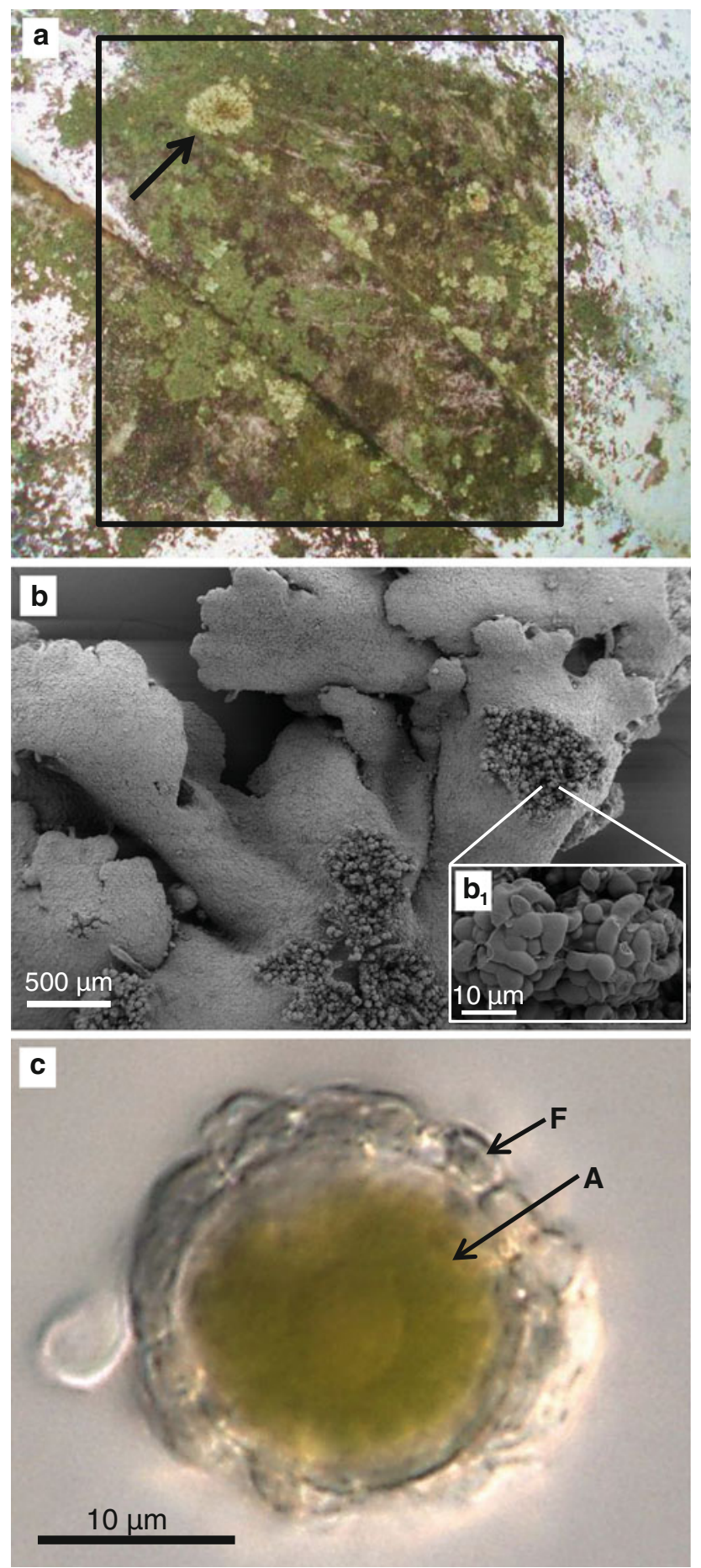

Fig. 2 Lichen thalli on old grown biofilm (sampling site B). aOverview image of sampling site B, with lichen thallus of Physcia sp. (black arrow). b Scanning electron micrograph of a lichen thallus with several soralia, inset $\mathbf{b}_{1}$ close-up view of soredia in a soralium. c Light micrograph of a lichenized Trebouxia cell ( $F$ fungal hyphae, $A$ algal cell)

alignment tool of the ARB program package. Potential chimeras were checked by Bellerophon (Huber et al. 2004). In addition, the first and the last $300 \mathrm{bp}$ of putative chimeras were compared with similar rRNA gene sequences in NCBI. Chimeras were excluded from the dataset.

Rarefaction curves and operational taxonomic units (OTUs) were calculated with MOTHUR (Schloss et al. 2009). OTUs were defined on $\geq 98 \%$ sequence similarity for 18S rRNA genes (Ragon et al. 2012). One sequence of each OTU with respect to green algae was selected and sequenced completely with $18 \mathrm{~S}$ standard sequencing primers: 34F, 370R, 891F, 1122F, 1122R, 1422F. Representative sequences were deposited in GenBank under the following accession numbers: JX391005-JX391026. The alignments for phylogenetic analysis were performed using MAFFT version 6 (Katoh and Toh 2008); small corrections were done by eye.

The phylogenetic tree was constructed with full-length sequences using the RAxML search algorithm for maximum likelihood (ML; Stamatakis et al. 2008), using the GTR $+\Gamma+$ I model with 100 replicates. The confidence of the tree topologies was tested by bootstrap analysis implemented in RAxML (100 replicates) and by Bayesian posterior probabilities (MB) using MrBayes 3.2 (Huelsenbeck and Ronquist 2001). Two parallel Markov chain Monte Carlo (MCMC) runs for two million generations each with one cold and three heated chains were conducted using the GTR $+\Gamma+$ I model, with trees sampled every 100 generations.

\section{Light and scanning electron microscopy}

Light microscopic observations were performed using an Olympus BX60 microscope (Tokyo, Japan) with Nomarski DIC optics with a ColorView III camera (Soft Imaging Systems, Münster, Germany) attached and micrographs were processed using the Cell^ $\mathrm{D}$ image software (Soft Imaging Systems).

For scanning electron microscopy (SEM), samples were fixed immediately after sampling in $2 \% \mathrm{w} / \mathrm{v}$ glutardialdehyde (EM grade, Sigma-Aldrich, Deisenhofen, Germany) and stored at $4{ }^{\circ} \mathrm{C}$ until further processing. Samples were dehydrated in an ascending ethanol series (15\% to $99 \%$ ), mounted on SEM sample holders and sputtered with Au-Pd (13.9 nm for 120 s). Samples were visualized in a SEM LEO 1530 Gemini (Zeiss, Oberkochen, Germany) combined with an INCA X-ACT EDX.

\section{Results}

Before surface cleaning, the marble sculpture exhibited obvious colonization by cryptogams, including fungi, algae and lichens (Fig. 1a, b). Surface cleaning was done mechanically with water, diluted hydrogen peroxide solution and a soft brush; if necessary, also mild detergent was 

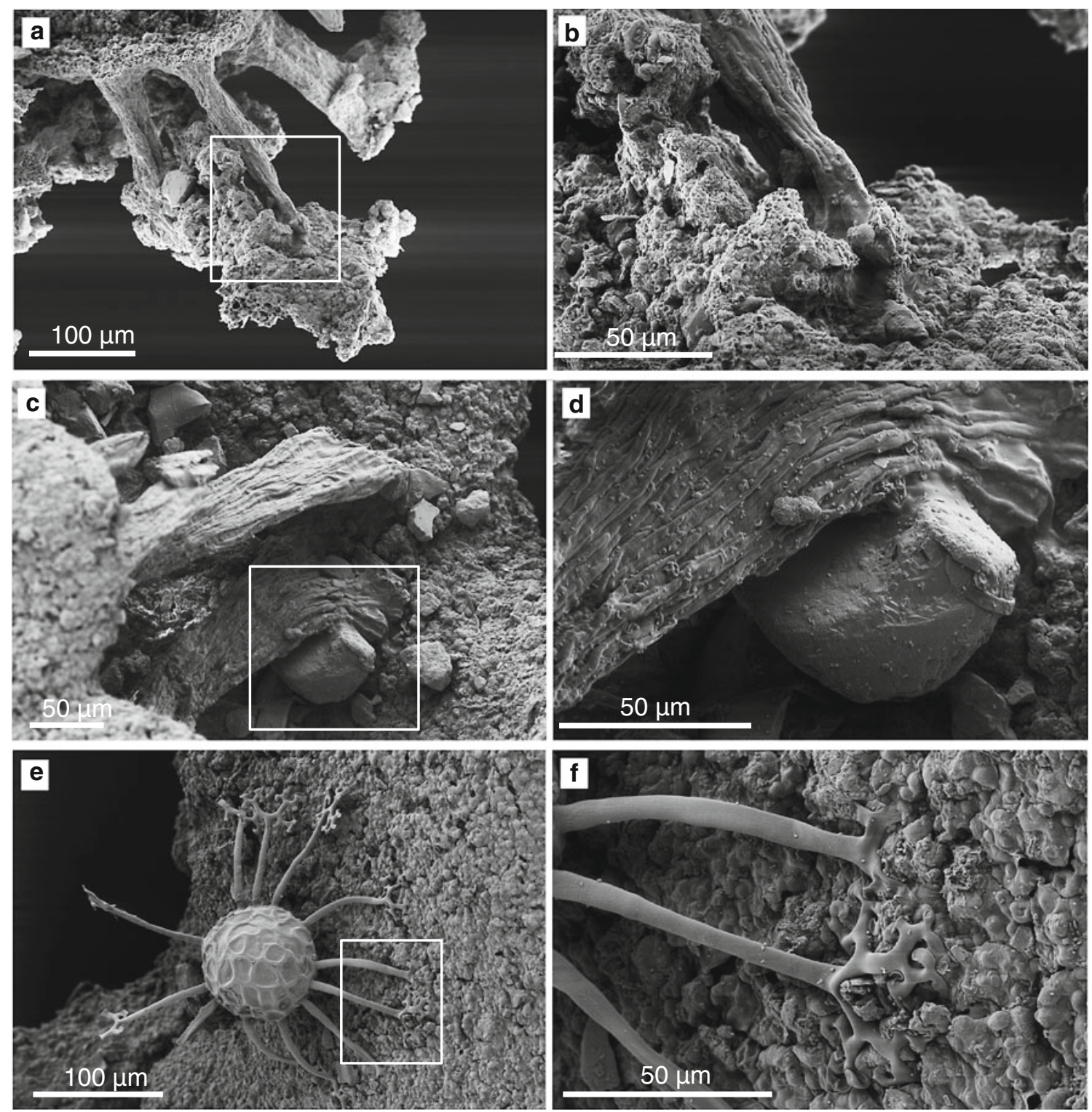

Fig. 3 Features of lichen thalli taken from old grown biofilm

e, $\mathbf{f}$ Chasmothecium of an Erysiphaceae representative attached on a lichen thallus, $\mathbf{f}$ detail of appendices of the chasmothecium anchored to the substratum

used. After cleaning, the white marble appeared to be completely free of surface staining or colonization to the naked eye, except from a rectangular $5 \times 10 \mathrm{~cm}$ area, which remained untreated. During cleaning, care was taken that neither water nor chemicals came in contact to the uncleaned area. One year after cleaning treatment (Fig. 1c, d) the monument appeared still white but some blackish spots, visible to the naked eye, already reappeared. On the sampling area B thalli of the foliose lichen Physcia sp. were obvious (Fig. 2a). SEM of a lichen thallus revealed reproductive structures like soredia (Fig. $2 b, b_{1}$ ). Light microscopy showed supposedly pre-lichenized Trebouxia cells surrounded by fungal hyphae (Fig. 2c). Lichen thalli were attached to the substrate by rhizines. These rootlike fungal structures were firmly associated with mineral particles detached from the surface of the sculpture (SEM, Fig. 3a-d).

SEM also revealed the presence of a plant pathogenic fungus on the lichen thallus. A chasmothecium (fruiting body) of a powdery mildew fungus (family Erysiphaceae) was anchored by appendices on the substratum (Fig. 3e, f).

Sequencing of 18S rRNA genes aiming at detection of eukaryotic algae and fungi was performed for environmental samples. In total $22218 \mathrm{~S}$ rRNA gene sequences were retrieved, 112 sequences from sample A (cleaned surface) and 110 sequences from sample B (uncleaned 


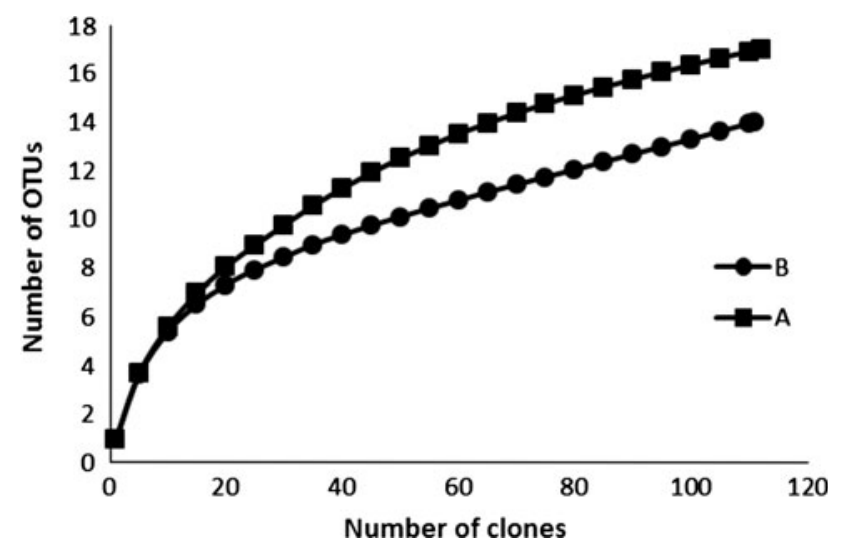

Fig. 4 Rarefaction curves determined for 18S rRNA gene clone libraries. The OTUs include green algal and fungal sequences from samples taken after cleaning treatment $(A)$ and from the uncleaned surface $(B)$

surface). Overall, 22 OTUs were received on the $98 \%$ sequence similarity level. Altogether 17 OTUs were retrieved from sample A and 14 OTUs from sample B. Rarefaction curves (Fig. 4) calculated for both samples showed the clone library coverage for algal and fungal sequences. The rarefaction curve from sample B reached almost a plateau. This was not the case for sample A, though also nearly full coverage of OTUs was reached.

With respect to green algae the samples indicated few differences (Fig. 5). Altogether ten green algal OTUs were retrieved, nine OTUs (69 clones) from sample A and seven OTUs (71 clones) from sample B. Phylogenetic analysis (Fig. 6) revealed that all sequences belong to the green algal class Trebouxiophyceae.

The green algal composition indicated a high similarity between both samples, six OTUs were shared by both (Table 1), one OTU were found only in sample B and three OTUs in sample A. In both sampling areas the Trebouxiarelated OTU 5 showed a clear dominance, with 27 clones from sample A and 34 clones from sample B (Table 1; Fig. 6). Furthermore, four OTUs could be assigned to other Trebouxia-related OTUs, with high clone numbers for
Fig. 6 Phylogenetic tree of Trebouxiophyceae based on 18S rRNA gene sequences. Maximum likelihood method (RAxML) based on 89 taxa and 1,801 positions. Thick lines indicate internal nodes that were received in maximum likelihood and Bayesian trees. Support values given as ML ( $>50 \%$ bootstrap values)/MB ( $>0.95$ Bayesian posterior probabilities). Sequences in bold represent full 18S rRNA gene sequences of clones; $A$ cleaned surface, $B$ uncleaned surface

OTU 4 and OTU 6 in both sampling areas. Stichococcusand Diplosphaera-related sequences were more abundant in sample A than in sample B, Desmococcus- (OTU 1) and Apatococcus-related (OTU 10) sequences were detected exclusively in sample A. Apatococcus sp.-related sequences could be separated in two distinct OTUs (Fig. 6), phylogenetically affiliated to Apatococcuslobatus SAG 2151 (OTU 10, exclusively in sample A, see above) and Apatococcus lobatus SAG 2037 (OTU 9), with respectively four clones in samples A and B.

With regard to fungi, both sampling areas differ markedly (Fig. 7). Altogether 12 fungal OTUs were retrieved, eight OTUs (43 clones) from sample A and seven OTUs (39 clones) from sample B. Just three OTUs were shared by both sampling sites (Table 2); next relatives according to BLASTN analysis were members of the family Teratosphaeriaceae (OTU 11), Rhinocladiella sp. (OTU 19) and Glyphium elatum (OTU 20).

The most abundant OTU in sample B was Rhinocladiella sp. (OTU 19, 22 clones), with $99 \%$ sequence similarity to the reference as revealed by BLASTN, while only two clones were discovered in the sample A. OTUs exclusively found in sample B were related to Bulgaria inquinans (OTU 13), a Capnodiales family member (OTU 15), Caloplaca demissa lichen fungus (OTU 16) and a Davidiellaceae family member (OTU 17).

The most abundant OTU in sample A 1 year after cleaning treatment was Sarcinomyces sp.-related OTU (OTU 14, 31 clones), with $99 \%$ similarity to the reference. Furthermore, exclusively found in this sample were OTUs related to Cladosporium bruhnei (OTU 12), Exophiala aquamarina (OTU 18), the uncultured Banisveld eukaryote
Fig. 5 Distribution of green algal OTUs (98\% cutoff) revealed few differences between the uncleaned surface and the surface after cleaning

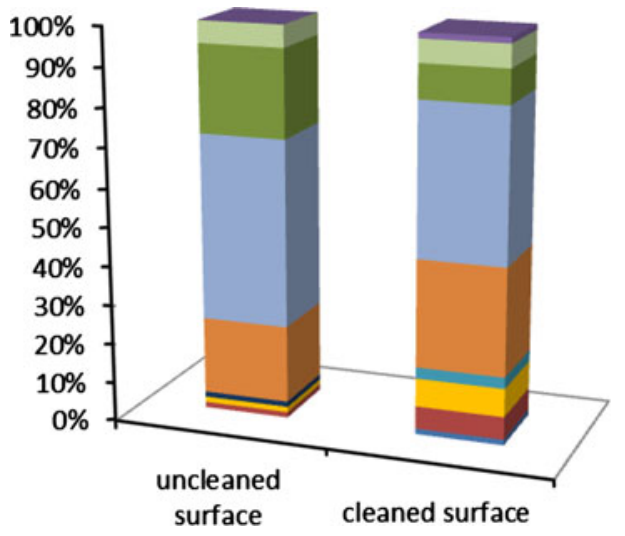

apatococcus SAG2151

Apatococcus SAG2037

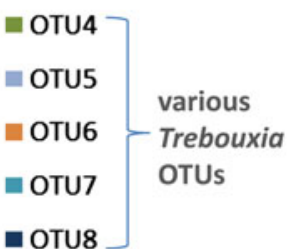

aTU8

Diplosphaera sp.

- Stichococcus sp.

Desmococcus olivaceus 


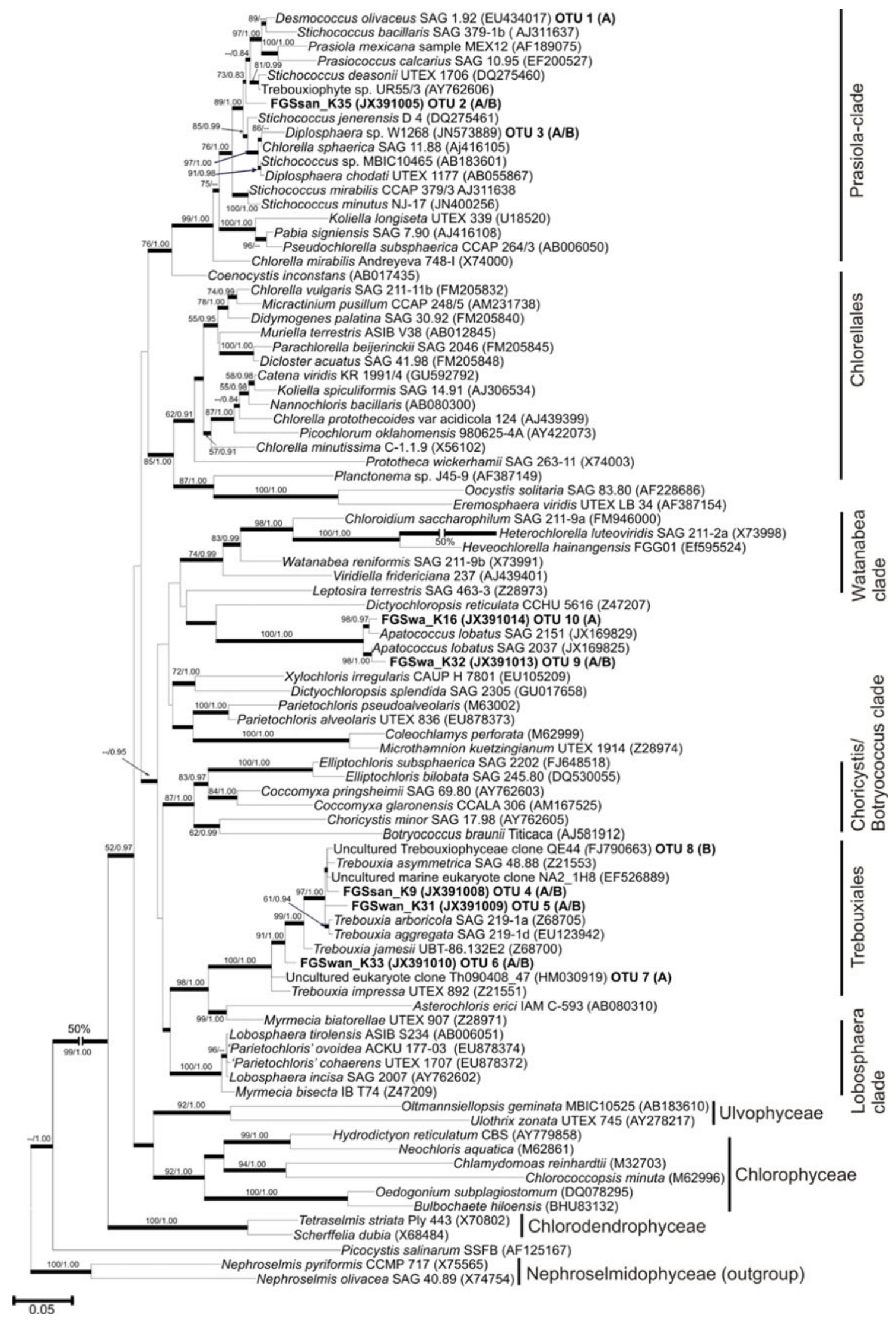


Table 1 Distribution of green algal OTUs in the samples of the cleaned (A) and uncleaned (B) surface

\begin{tabular}{|c|c|c|c|c|c|}
\hline \multirow[t]{2}{*}{ OTU $98 \%$} & \multicolumn{2}{|c|}{ No. of clones } & \multirow[t]{2}{*}{ Representative clone } & \multirow[t]{2}{*}{ Acc. No. } & \multirow[t]{2}{*}{ Closest relative (\% similarity) } \\
\hline & A & $\mathrm{B}$ & & & \\
\hline 1 & 1 & & FGSwan_K6/(A) & JX391007 & Desmococcus olivaceus SAG 1.92, EU434017 (99 \%)* \\
\hline 2 & 4 & 1 & FGSsan_K35/(B)* & JX391005 & $\begin{array}{l}\text { Trebouxiophyte sp. UR55/3, AY762606 (99 \%), } \\
\text { Stichococcus sp. }\end{array}$ \\
\hline 3 & 5 & 1 & FGSwa_K37/(A) & JX391006 & Diplosphaera sp. W1268, JN573889 (99 \%)* \\
\hline 4 & 6 & 16 & FGSsan_K9/(B)* & JX391008 & $\begin{array}{l}\text { Uncultured marine eukaryote clone NA2_1H8, } \\
\text { EF526889 (99\%), Trebouxia sp. }\end{array}$ \\
\hline 5 & 27 & 34 & FGSwan_K31/(A)* & JX391009 & $\begin{array}{l}\text { Uncultured marine eukaryote clone NA2_1H8, } \\
\text { EF526889 }(99 \%) \text {, Trebouxia sp. }\end{array}$ \\
\hline 6 & 19 & 14 & FGSwan_K33/(A)* & JX391010 & Trebouxia impressa UTEX 892, Z21551 (99 \%) \\
\hline 7 & 2 & & FGSwa_K17/(A) & JX391012 & $\begin{array}{l}\text { Uncultured eukaryote clone Th090408_47, HM030919 } \\
(99 \%)^{*} \text {, Trebouxia sp. }\end{array}$ \\
\hline 8 & & 1 & FGSsa_K43/(B) & JX391011 & $\begin{array}{l}\text { Uncultured Trebouxiophyceae clone QE44, FJ790663 } \\
(98 \%)^{*} \text {, Trebouxia sp. }\end{array}$ \\
\hline 9 & 4 & 4 & FGSwa_K32/(A)* & JX391013 & $\begin{array}{l}\text { Uncultured eukaryote clone Th090408_11, HM030915 } \\
\text { (99\%), Apatococcus sp. }\end{array}$ \\
\hline 10 & 1 & & FGSwa_K16/(A)* & JX391014 & $\begin{array}{l}\text { Uncultured eukaryote clone Th090408_11, HM030915 } \\
\text { (99\%), Apatococcus sp. }\end{array}$ \\
\hline
\end{tabular}

* Representative full length sequence in phylogenetic analysis

Fig. 7 Distribution of fungal OTUs (98\% cutoff) revealed clear differences between the uncleaned surface and the surface after cleaning clone (100\% sequence similarity)/Rhodotorula aurantiaca JCM 3771 (AB030354) with $99 \%$ sequence similarity (OTU 21) and Cryptococcus albidus (OTU 22).

\section{Discussion}

Colonization of monuments, including marble sculptures, has been already documented in various studies (e.g., Albertano and Urzì 1999; Ortega-Calvo et al. 1995; Lamenti et al. 2000; Gorbushina et al. 2002; Hallmann et al. 2011a). In the case presented here, the surface of the marble sculpture was affected by biodeterioration in two different ways. Heavy blackish stains covered the entire

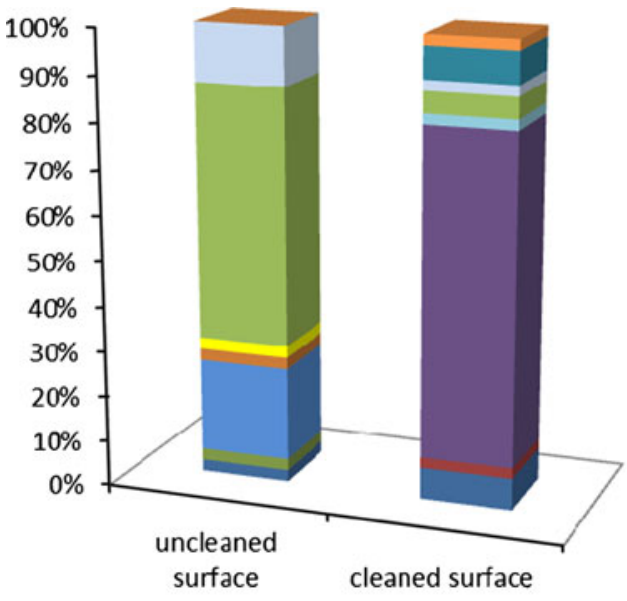

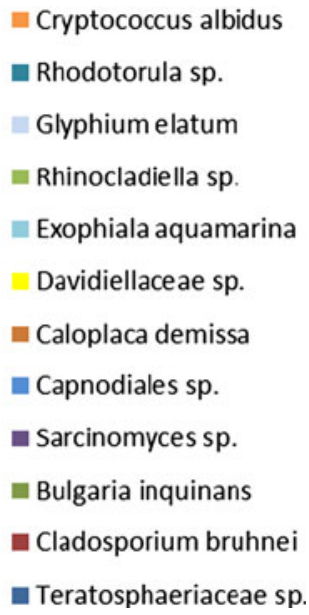

surface and single mineral particles were detached from the surface and became attached to the lichen plectenchyme. Thus, one may expect that both effects may be temporarily stopped or reduced by surface cleaning and other treatments. However, by far most of previous studies just show colonization at one time point, and the gradual decrease of the cleaning effect by recolonization has been rarely addressed so far. One may speculate that after (re-) colonization has completed, the microbial communities are stable for several years "old grown" biofilms), representing a snapshot of a "climax" community. Our study documents the re-colonization 1 year after cleaning treatment in comparison to the "old grown" biofilm on the same marble sculpture. 
Table 2 Distribution of fungal OTUs in the samples of the cleaned (A) and uncleaned (B) surface

\begin{tabular}{|c|c|c|c|c|c|}
\hline \multirow[t]{2}{*}{ OTU $98 \%$} & \multicolumn{2}{|c|}{ No. of clones } & \multirow[t]{2}{*}{ Representative clone } & \multirow[t]{2}{*}{ Acc. No. } & \multirow[t]{2}{*}{ Closest relative (\% similarity) } \\
\hline & A & $\mathrm{B}$ & & & \\
\hline 11 & 3 & 1 & FGSwe_K21/(A) & JX391015 & Teratosphaeriaceae sp. strain CCFEE 5508, GU250358 (99 \%) \\
\hline 12 & 1 & & FGSwe_K48/(A) & JX391016 & Cladosporium bruhnei strain CPC 5101, AY251096 (99 \%) \\
\hline 13 & & 1 & FGSsan_K4(/B) & JX391019 & Bulgaria inquinans isolate 93, EU107259 (98 \%) \\
\hline 14 & 31 & & FGSwe_K18/(A) & JX391018 & Sarcinomyces sp. isolate MA 4760, AJ972809 (99 \%) \\
\hline 15 & & 8 & FGSse_K24/(B) & JX391017 & Capnodiales sp. strain CCFEE 5502, GU250357 (100\%) \\
\hline 16 & & 1 & FGSse_K7/(B) & JX391024 & Caloplaca demissa, AF515609 (98 \%) \\
\hline 17 & & 1 & FGSse_K17/(B) & JX391020 & Davidiellaceae sp. strain CCFEE 5414, GU250343 (97 \%) \\
\hline 18 & 1 & & FGSwe_K3/(A) & JX391021 & Exophiala aquamarina strain CBS 119918, JN856012 (98\%) \\
\hline 19 & 2 & 22 & FGSse_K11/(B) & JX391022 & Rhinocladiella sp. Isolate MA 4765, AJ972862 (99 \%) \\
\hline 20 & 1 & 5 & FGSse_K4/(B) & JX391023 & Glyphium elatum strain CBS 268.34, AF346419 (99 \%) \\
\hline 21 & 3 & & FGSwe_K23/(A) & JX391025 & $\begin{array}{l}\text { Uncult. Banisveld euk. clone P1-3m6, EU091832 (100 \%), } \\
\text { Rhodotorula aurantiaca (99\%) }\end{array}$ \\
\hline 22 & 1 & & FGSwe_K28(A) & JX391026 & Cryptococcus albidus strain WY-1, HQ231895 (99 \%) \\
\hline
\end{tabular}

The green algal sequences in the "old grown" biofilm (sample B) and on the cleaned surface (sample A) belong all to Trebouxiophyceae; members of this green algal class are mostly aerophytic or soil algae (Friedl and Rybalka 2012). Adaptations against desiccation and UV irradiation like thick cell walls, mucilage sheaths and Mycosporinelike amino acids (MAAS) are common for aerophytic algae (Karsten et al. 2005a, b). The occurrence of the trebouxiophyceaen genera Apatococcus, Desmococcus, Stichococcus, Diplosphaera and Trebouxia on stone substrates is well known (Hallmann et al. 2011a; Ragon et al. 2012).

On the $98 \%$ similarity level two OTUs of Apatococcus were detected; the phylogenetic analysis confirmed two distinct groups (cf. Fig. 6). The cell package forming green algae Apatococcus lobatus is the most common aerophytic alga (Gärtner 1994), abundant on natural stone substrata in the urban environment (Rindi 2007). The resistance of Apatococcus against pollution, desiccation and high UV radiation is mainly due to thick cell walls and typical cytosolic "stress metabolites" like the polyols ribitol and erythritol (Barkman 1969; Gustavs et al. 2011). Apatococcus was detected in both samples (old grown biofilm and cleaned area). Hitherto, lichen symbiosis for Apatococcus lobatus could not be definitively proven (Gärtner and Ingolic 1989), but a close association with fungal hyphae was observed (Edlich 1936). Desmococcus, another cell packages forming trebouxiophyte, but phylogenetically distant from Apatococcus (Fig. 6), a very common aeroterrestrial green algae (Rindi 2007) was also detected on the cleaned surface.

The dominance of different phylotypes of the lichen photosymbiont Trebouxia on both surfaces may be surprising since lichen thalli were present in the old grown biofilm, but not detected on the cleaned surface. However, Trebouxia has been frequently described in terrestrial habitats even when identifiable lichens were absent (Gärtner 1994; Macedo et al. 2009). Furthermore, soredia (asexual reproductive structures) were observed by SEM on the surface of a lichen thallus (Fig. 2b) and single Trebouxia cells were closely associated with fungal hyphae (cf. Fig. 2c). This lichenization without an identifiable lichen thallus, in particular as asexual propagules or thallus fragments, is common for Trebouxia (Ahmadjian 1988). Thus, various OTUs of Trebouxia could be detected possibly because of these dispersal structures of different lichens, colonizing tree bark and stone monuments nearby the cleaned sculpture, while obvious lichen thalli were absent on the cleaned sampling site A.

The green alga Stichococcus and Diplosphaera, both affiliated to Prasiolales-clade, were also discovered on both sampling areas. Stichococcus and Diplosphaera are known as lichen photobionts (Thüs et al. 2011). In addition, Stichococcus is an ubiquitous and rapid colonizer known from nitrogen rich sites (Ettl and Gärtner 1995). Since the monument is situated under a tree, bird droppings (Hallmann et al. 2011a) may contribute to favorable conditions for Stichococcus. Generally, these photosynthetic microorganisms cause staining by photosynthetic pigments and may be involved in stone decay by secretion of organic acids and indirectly by supporting growth of other microorganisms like fungi and bacteria (Ariño et al. 1997; Polo et al. 2010).

Interestingly, fungal OTUs markedly differed in our studied samples. Eight of 12 fungal OTUs belong to the classes Dothideomycetes and Eurotiomycetes, which 
include numerous rock inhabiting fungi involved in stone biodeterioration (Gorbushina et al. 1993; Wollenzien et al. 1997; Ruibal et al. 2009).

The most abundant OTU 14 on the cleaned surface (sample A) is related to Sarcinomyces sp. isolate MA 4760, next related to Sarcinomyces petricola (Sert et al. 2007; Wollenzien et al. 1997), whereas the most abundant OTU 19 retrieved from the old grown biofilm (sample B) is related to Rhinocladiella sp. MA 4765 isolated from antique marble in Turkey (Sert et al. 2007). The black filamentous Rhinocladiella is free living, but also parasitic on lichens (Harutyunyan et al. 2008): Sarcinomyces is affiliated to meristematic black yeasts.

Whereas Sarcinomyces sp. was totally absent in the old grown biofilm, small number of Rhinocladiella sp. clones were also found on the cleaned surface. Thus one may speculate that Sarcinomyces appears to be a rapid colonizer, but was presumably outcompeted in our old grown biofilm by other fungi like Rhinocladiella. Just two OTUs in addition to Rhinocladiella sp. were shared by both surfaces, with just one clone in either sample A or sample B: Glyphium elatum (normally on wood, non-lichenized) and one OTU included in the family Teratosphaeriaceae (associated with Eucalyptus leaf diseases and stem cankers).

Only present in the old grown biofilm was Bulgaria inquinans, a saprobiontic fungus on tree bark, a species of the order Capnodiales, an epiphytic black fungus on plant leaves and often associated with the honeydew. In addition, exclusive in the old biofilm were Caloplaca demissa, a lichen fungus, with cyanobacteria instead of green algae in the thallus and a species of the family Davidiellaceae (with some cryptoendolithic representatives; Selbmann et al. 2005; Hallmann et al. 2011b).

Only presented on the cleaned surface were free living fungi like Cladosporium, well known from marble (Wollenzien et al. 1995), Exophiala aquamarina (a black yeast), an uncultured Banisveld eukaryotic clone (next related culture Rhodotorula aurantiaca, a yeast) and Cryptococcus albidus (cosmopolitan, e.g., on plants).

Most fungi were affiliated to "black fungi". In these groups the black pigment melanin is incorporated in vegetative hyphae, which provides protection against high UV irradiance (Bell and Wheeler 1986). It is reasonable to assume that, besides algal pigments, melanin contributes to the blackish color of the old grown biofilm. Black fungi are frequently found in conjunction with honeydew coverings: Typically, honeydew is secreted by plant-sucking aphids and scale insects (e.g., Auclair 1963). When the plant is massively infested by these insects, the resulting honeydew coverings of surfaces located underneath the plant are colonized by black fungi (Hallmann et al. 2011a). The investigated marble sculpture was situated under a tree, which causes a favorable microclimate (protection against high irradiation and evaporation; e. g. Weber et al. 2007) and provides nutrients as honeydew, dead plant material and bird droppings for microbial growth. A continuous input from the canopy is also documented by powdery mildew fruiting bodies (chasmothecia) scattered on the surface of the lichen thalli (Fig.3 e). Powdery mildew is a fungal disease affecting the tree leaves (Glawe 2008 and references therein).

Little experience has been collected so far on re-colonization of stone surfaces by microorganisms after cleaning. Though directly after cleaning with biocides, no remaining organisms could be detected (Polo et al. 2010), a long-term experiment documented re-colonization after cleaning treatment over 6 years (Lamenti et al. 2000). However, just enrichment culturing was used in this approach, which will greatly alter the microbial community before analysis. Twelve months after cleaning Coccomyxa sp. was observed as the dominant first colonizer. Six years after cleaning treatment, the community was again identical to an unrestored statue with green algae like Coccomyxa, Apatococcus and Stichococcus.

Miller et al. (2008) analyzed the biofilm development on a stone surface under laboratory conditions, using a molecular approach. One month after inoculation of the cleaned surface with an active growing microbial culture a green layer was observed; fungi were observed after 3 months. The detected eukaryotic phototrophic microorganisms belonged to the genera Stichococcus, Trebouxia, Myrmecia and Chlorella.

In our study, we could show that the cleaned re-colonized surface differs with respect to the fungal community, but not with respect to the green algal community, 1 year after re-colonization started. Up to now, this effect appears to be unavoidable, if not repeated cleaning and/or biocide treatment is applied.

It must be kept in mind that early re-colonizers of a cleaned surface might be even more deleterious with respect to biogenic weathering than an old grown biofilm community (cf. Gaylarde et al. 2012).

Acknowledgment This is Courant Research Centre Geobiology publication no. 113 .

Open Access This article is distributed under the terms of the Creative Commons Attribution License which permits any use, distribution, and reproduction in any medium, provided the original author(s) and the source are credited.

\section{References}

Ahmadjian V (1988) The lichen alga Trebouxia: does it occur freeliving? Plant Syst Evol 158:243-247

Albertano P, Urzì C (1999) Structural interactions among epilithic cyanobacteria and heterotrophic microorganisms in Roman hypogea. Microb Ecol 38:244-252 
Altschul SF, Gish W, Miller W, Myers EW, Lipman DJ (1990) Basic local alignment search tool. J Mol Biol 215:403-410

Ariño X, Hernandez-Marine M, Saiz-Jimenez C (1997) Colonization of Roman tombs by calcifying cyanobacteria. Phycologia $36: 366-373$

Auclair JL (1963) Aphid feeding and nutrition. Ann Rev Entomol 8:439-490

Barkman JJ (1969) Phytosociology and ecology of cryptogamic epiphytes. Van Gorcum Ltd., Assen

Bell AA, Wheeler MH (1986) Biosynthesis and functions of fungal melanins. Annu Rev Phytopathol 24:411-451

Cappitelli F, Zanardini E, Ranalli G, Mello E, Daffonchio D, Sorlini C (2006) Improved methodology for bioremoval of black crusts on historical stone artworks by use of sulfate-reducing bacteria. Appl Environ Microbiol 72:3733-3737

Cappitelli F, Principi P, Pedrazzani R, Toniolo L, Sorlini C (2007) Bacterial and fungal deterioration of the Milan cathedral marble treated with protective synthetic resins. Sci Total Environ 385: 172-181

Edlich F (1936) Einwirkung von Temperatur und Wasser auf aerophile Algen. Arch Microbiol 7:62-109

Ettl H, Gärtner G (1995) Syllabus der Boden-, Luft- und Flechtenalgen. Gustav Fischer, Stuttgart

Friedl T, Rybalka N (2012) Systematics of the green algae: A brief introduction to the current status. In: Lüttge U, Beyschlag W, Francis D, Cushman J (eds) Progress in Botany No. 73. Springer, Heidelberg, pp 259-280

Gärtner G (1994) Zur Taxonomie aerophiler grüner Algenanflüge an Baumrinden. Ber. nat.-med. Verein Innsbruck 81:51-59

Gärtner G, Ingolić E (1989) Ein Beitrag zur Kenntnis von Apatococcus lobatus (Chlorophyta, Chaetophorales, Leptosiroideae). Plant Syst Evol 164:133-143

Gaylarde CC, Rodríguez CH, Navarro-Noya YE, Ortega-Morales BO (2012) Microbial biofilms on the sandstone monuments of the Angkor Wat complex, Cambodia. Curr Microbiol 64:85-92

Glawe DA (2008) The Powdery Mildews: a review of the world's most familiar (yet poorly known) plant pathogens. Annu Rev Phytopathol 46:27-51

Gorbushina AA, Krumbein WE, Hamman CH, Panina L, Soukharjevski S, Wollenzien U (1993) Role of black fungi in color-change and biodeterioration of antique marbles. Geomicrobiol $\mathrm{J} 11$ : 205-221

Gorbushina AA, Lyalikova NN, Vlasov DYu, Khizhnyak TV (2002) Microbial communities on the monuments of Moscow and St. Petersburg: biodiversity and trophic relations. Microbiology 71: 350-356

Grant C (1982) Fouling of terrestrial substrates by algae and implications for control-a review. Intl Biodeterior Bull 18:57-65

Gromov BV (1963) The microflora of deteriorating brick, plaster and marble. Vestn Len Univ Ser Biol 3:69-77

Gustavs L, Görs M, Karsten U (2011) Polyol patterns in biofilmforming aeroterrestrial green algae (Trebouxiophyceae, Chlorophyta). J Phycol 47:533-537

Hallmann C, Rüdrich J, Enseleit M, Friedl T, Hoppert M (2011a) Microbial diversity on a marble monument: a case study. Environ Earth Sci 63:1701-1711

Hallmann C, Fritzlar D, Stannek L, Hoppert M (2011b) Ascomycete fungi on dimension stone of the "Burg Gleichen", Thuringia. Environ Earth Sci 63:1713-1722

Hallmann C, Stannek L, Fritzlar D, Hause-Reitner D, Friedl T, Hoppert M (2013) Molecular diversity of phototrophic biofilms on building stone. FEMS Microbiol Ecol. doi:10.1111/ 1574-6941.12065

Hamby RK, Sim LE, Issel LE, Zimmer EA (1988) Direct RNA sequencing: optimization of extraction and sequencing techniques for work with higher plants. Plant Mol Biol Rep 6:179-197
Harutyunyan S, Muggia L, Grube M (2008) Black fungi in lichens from seasonally arid habitats. Stud Mycol 61:83-90

Hepperle D (2004) SeqAssem ( . A sequence analysis tool, counting assembler and trace data visualization tool for molecular sequences. Win32-Version. Distributed by the author via: http:// www.seqeuntix.de

Hodač L, Hallmann C, Rosenkranz H, Fasshauer F, Friedl T (2012) Molecular evidence for the wide distribution of two lineages of terrestrial green algae (Chlorophyta) over tropics to temperate zone. ISRN Ecology, Article ID 795924. doi:10.5402/2012/ 795924

Huber T, Faulkner G, Hugenholtz P (2004) Bellerophon; a program to detect chimeric sequences in multiple sequence alignments. Bioinformatics 20:2317-2319

Huelsenbeck JP, Ronquist F (2001) MRBAYSE: Bayesian inference of phylogenetic trees. Bioinformatics 17:754-755

Karsten U, Schumann R, Häubner N, Friedl T (2005a) Lebensraum Fassade: aeroterrestrische Mikroalgen. Biol unserer Zeit 1:20-30

Karsten U, Friedl T, Schumann R, Hoyer K, Lembcke S (2005b) Mycosporine-like amino acids and phylogenies in green algae: Prasiola and its relatives from the Trebouxiophyceae (Chlorophyta). J Phycol 41:557-566

Katoh K, Toh H (2008) Recent developments in the MAFFT multiple sequence alignment program. Brief Bioinform 9:286-298

Konkol NR, McNamara CJ, Blanchette RA, May E, Mitchell R (2008) Microbes can damage but also help restore artifacts. Microbe 3:563-567

Lamenti G, Tiano P, Tomaselli L (2000) Biodeterioration of ornamental marble statues in the Boboli Gardens (Florence, Italy). J Appl Phycol 12:427-433

Lan W, Li H, Wang WD, Katayama Y, Gu JD (2010) Microbial community analysis of fresh and old microbial biofilms on Bayon temple sandstone of Angkor Thom, Cambodia. Microb Ecol 60:105-115

Ludwig W, Strunk O, Westram R, Richter L, Meier H, Yadhukumar, Buchner A, Lai T, Steppi S, Jobb G, Förster W, Brettske I, Gerber S, Ginhart AW, Gross O, Grumann S, Hermann S, Jost R, König A, Liss T, Lüßmann R, May M, Nonhoff B, Reichel B, Strehlow R, Stamatakis A, Stuckmann N, Vilbig A, Lenke M, Ludwig T, Bode A, Schleifer KH (2004) ARB: a software environment for sequence data. Nucl Acids Res 32:1363-1371

Macedo MF, Miller AZ, Dionísio A, Saiz-Jimenez C (2009) Biodiversity of cyanobacteria and green algae on monuments in the Mediterranean Basin: an overview. Microbiology 155:3476-3490

Maravelaki-Kalaitzaki P, Zafiropulos V, Fotakis C (1999) Excimer laser cleaning of encrustation on Pentelic marble: procedure and evaluation of the effects. Appl Surf Sci 148:92-104

McNamara CJ, Mitchell R (2005) Microbial deterioration of historic stone. Front Ecol Environ 3:445-451

McNamara CJ, Perry TD IV, Bearce KA, Hernandez-Duque G, Mitchell R (2006) Epilithic and endolithic bacterial communities in limestone from Maya archeological site. Microb Ecol 51: $51-64$

Miller AZ, Laiz L, Gonzalez JM, Dionísio A, Macedo MF, Saiz-Jimenez C (2008) Reproducing stone monument photosynthetic-based colonization under laboratory conditions. Sci Total Environ 405:278-285

Moropoulou A, Tsiourva Th, Bisbikou K, Tsantila V, Biscontin G, Longega G, Groggia M, Dalaklis E, Petritaki A (2002) Evaluation of cleaning procedures on the facades of the bank of Greece historical building in the center of Athens. Build Environ 37:753-760

Ortega-Calvo JJ, Ariño X, Hernandez-Marine M, Saiz-Jimenez C (1995) Factors affecting the weathering and colonization of monuments by phototrophic microorganisms. Sci Total Environ 167:329-341 
Polo A, Cappitelli F, Brusetti L, Principi P, Villa F, Giacomucci L, Ranalli G, Sorlini C (2010) Feasibility of removing surface deposits on stone using biological and chemical remediation methods. Microb Ecol 60:1-14

Ragon M, Fontaine MC, Moreira D, López-García P (2012) Different biogeographic patterns of prokaryotes and microbial eukaryotes in epilithic biofilms. Mol Ecol 21:3852-3868

Rindi F (2007) Diversity, distribution and ecology of green algae and cyanobacteria in urban habitats. In: Seckbach J (ed) Algae and cyanobacteria in extreme environments. Springer, Dordrecht, pp 571-582

Ruibal C, Gueidan C, Selbmann L, Gorbushina AA, Crous PW, Groenewald JZ, Muggia L, Grube M, Isola D, Schoch CL, Staley JT, Lutzoni F, de Hoog GS (2009) Phylogeny of rock-inhabiting fungi related to Dothideomycetes. Stud Mycol 64:123-133

Saiz-Jimenez C (1995) Deposition of anthropogenic compounds on monuments and their effect on airborne microorganisms. Aerobiologia 11:161-175

Schloss PD, Westcott SL, Ryabin T, Hall JR, Hartmann M, Hollister EB, Lesniewski RA, Oakley BB, Parks DH, Robinson CJ, Sahl JW, Stres B, Thallinger GG, Van Horn DJ, Weber CF (2009) Introducing mothur: open-source, platform-independent, community-supported software for describing and comparing microbial communities. Appl Environ Microbiol 75:7537-7541

Selbmann L, de Hoog GS, Mazzaglia A, Friedmann EI, Onofri S (2005) Fungi at the edge of life: cryptoendolithic black fungi from Antarctic desert. Stud Mycol 51:1-32

Sert HB, Sterflinger K (2010) A new Coniosporium species from historical marble monuments. Mycol Progress 9:353-359

Sert HB, Sümbül H, Sterflinger K (2007) Microcolonial fungi from antique marbles in Perge/Side/Termessos (Antalya/Turkey). Antonie Van Leeuwenhoek 91:217-227
Stamatakis A, Hoover P, Rougemont J (2008) A rapid bootstrap algorithm for the RAxML Web servers. Syst Biol 57:758-771

Sterflinger K, Krumbein WE (1997) Dematiaceous fungi as a major agent of biopitting for Mediterranean marbles and limestones. Geomicrobiol J 14:219-230

Thüs H, Muggia L, Pérez-Ortega S, Favero-Longo SE, Joneson S, O'Brien H, Nelsen MP, Duque-Thüs R, Grube M, Friedl T, Brodie J, Andrew CJ, Lücking R, Lutzoni F, Gueidan C (2011) Revisiting photobiont diversity in the lichen family Verrucariaceae (Ascomycota). Eur J Phycol 46:399-415

Warscheid Th, Braams J (2000) Biodeterioration of stone: a review. Int Biodeter Biodegr 46:343-368

Weber J, Beseler S, Sterflinger K (2007) Thin-section microscopy of decayed crystalline marble from the garden sculptures of Schoenbrunn Palace in Vienna. Mater Charact 58:1042-1051

Wollenzien U, de Hoog GS, Krumbein WE, Urzí C (1995) On the isolation of microcolonial fungi occurring on and in marble and other calcareous rocks. Sci Total Environ 167:287-294

Wollenzien U, de Hoog GS, Krumbein W, Uijthof JMJ (1997) Sarcinomyces petricola, a new microcolonial fungus from marble in the Mediterranean basin. Antonie Van Leeuwenhoek 71:281-288

Yang FW, Liu Y, Zhu YC, Long SJ, Zuo GF, Wang CQ, Guo F, Zhang BJ, Jiang SW (2012) Conservation of weathered historic sandstone with biomimetic apatite. Chin Sci Bull 57:2171-2176

Young ME, Urquhart DCM (1998) Algal growth on building sandstones: effects of chemical stone cleaning methods. Q J Eng Geol Hydrogeol 31:315-324

Zanardini E, Abbruscato P, Ghedini N, Realini M, Sorlini C (2000) Influence of atmospheric pollutants on the biodeterioration of stone. Int Biodeter Biodegr 45:35-42 